\title{
空間時系列モデルの大気污染質レベル值予測への適用*
}

$$
\text { 大 恵 俊一 郎** }
$$

\section{Application of Space-Time Series Model to the Prediction of Air Pollution Levels*}

\author{
Shunichiro $\mathrm{OE}^{* *}$
}

\begin{abstract}
This paper deals with a prediction method of air pollution levels by using the spacetime series model which considers both time lag and spatial lag to introduce the concept of spatial spread. As it is considered that the prediction accuracy is influenced by the wind direction, We propose a new method to take the information of wind direction in the model. From the simulation results, it is shown that the prediction accuracy based on the space-time series model is superior to that based on the ordinary time series model which considers time lag only.
\end{abstract}

\section{1. まえがき}

大気污染の予測方法としては，(1) 物理モデルを用い る方法と（2）非物理モデルを用いる方法がある. 前者は 移流, 上昇, 拡散などの諸過程をモデル化し, 数値化し て解析するあのであり, 後者は過去の污染質レベル值, 気象条件などのデータから統計モデルを作って, 予測する あのである. 予測の目的としては, 現状の改善, 将来の 発生源に対する事前予測（長期予測）と光化学オキシダ ントの予報などに使用される数時間先の予測（短期予測） に大別される. 物理モデルとしては拡散モデルが主とし て用いられ，乙れらは主に事前予測などの長期予測に使 用されている。乙のモデルを用いる際に必要な条件を厳 密に満たすととは難しく，しかも計算に必要なデー夕を 正確に得ることは困難な場合が多い。 また, 大気は, 乱 流, 拡散のような不確定要素が多いので, 大気污染現象 を支配する普遍法則を厳密に見い出すことは不可能であ る. このために, 大気污染質レベル値の変動を確率現象 とみなし，観測データを客観的に処理することにより作 られるモデル，すなわち非物理モデルが開発されている. このモデルには, 時系列モデル, 重回㷌モデル, および GMDH によるモデルなどがあり，乙れらを用いた短期 予測手法が提案されている

* 原稿受付 1989. 11. 29

** 徳島大学 工学部 Faculty of Engineering, University of Tokushima ; Minamijosaojima, Tokushima 770, JAPAN

Key Words : prediction of air pollution levels, identification, space-time autoregressive model, weighting matrix, wind direction.
規則性を有するデータの時間変動を表現するととに高い 能力を持っており, 污染質レベル值の短期予測に適した モデルである. 大気污染はスケールが大きく, 空間的に 広く分布し, しかも地形や風などの自然環境の影響を 強く受ける. したがって, てれらの情報をモデルの中に 取り入れる必要があり，乙れまでに，空間情報や風など の気象情報をモデルの中に取り込む試みがなされてい $3^{4 \sim 7}$. 大気污染の監視は対象之する領域内の多くの観 測点で行なわれており, 本論文では, それらの観測地点 で同時刻に得られた観測值を観測地点数の次元を持つ観 測值ベクトルとし, てのベクトルから構成される多次元 時系列に時系列モデルをあてはめて短期予測を行なう問 題を考察する. そのためのモデルの一つとして多次元時 系列モデルがある ${ }^{8,9}$. 乙のモデルは空間情報や気象情報 などを表わすパラメータを特に用いず，それらの情報は 多次元時系列モデルのパラメータに含めて考えている. 一方, 空間的な位置関係, 山や川などの自然環境, さら には交通網のような輸送の容易性などの物理的情報をパ ラメータとしてモデルの中に取り込むてとが可能な構造 を持つ空間時系列モデルが提案されている ${ }^{10-12}$. このモ デルは，乙のような物理的情報をモデルの中にパラメー 夕として取り入れるてとが可能になっているとてろに大 きな特徴がある. したがって完全な非物理モデルではな く, 物理モデルの性質を一部持った非物理モデルと考え ることが出来る. 本論文では，乙のような特徴を持つ空 間時系列モデルを前述の大気污染質レベル值の多次元時 系列デー夕に適用し，その予測を行なう方法を提案する. 特に, 大気污染は風の影響を受け易いので時系列モデル 
の中に風向きの情報を取り入れることが必要であり，さ らに風向きは時刻とともに変化するので時変系の時系列 モデルを構成することが望ましい. しかし, 従来の時間 遅れのみを考慮した時系列モデルでは風向きの情報を取 り入れることは困難であり，風向きを考慮した時系列モ デルはまだ開発されていない，そこで，本論文では，風 向きを考慮に入れた空間時系列モデルを用いて大気污染 質レベル值を予測する手法む提案する. さらに，本手法 を徳島県東部地域の 7 か所で観測された大気污染質レベ ル值へ適用し, その予測結果と従来の空間的広がりを考 慮していない時系列モデルを用いた結果との予測精度を 比較検討し, 空間時系列モデルの優位性を定量的に検証 する.

\section{2. 空間時系列モデルの要約}

空間時系列モデルは通常の時系列モデルに用いられる 時間遅れ以外に空間的広がりの概念を取り入れたもので あり，通常の時系列モデルの考え方を拡張するてとによっ て得られる. こてでは, 大気污染質レベル值の予測方法 の提案の際に必要となる空間時系列モデルについて, P. E. Pfeifer による諸定義, 特性, および空間自己相 関関数·空間偏自己相関関数について要約する ${ }^{10 \sim 12}$.

\section{1 空間遅れ作用素と重み係数}

空間時系列モデルについては，通常の時系列モデルに 用いられる時間遅れ以外に空間遅れという概念を取り入 れなければならない.乙の空間遅れとは, Fig.1亿示 すように空間的に固定された二つの場所間の距離を相対 的に表わしたあのであり，ある場所を中心に考える之， そこに近い場所群から順に $1,2, \cdots$ と空間遅れ次数をつ

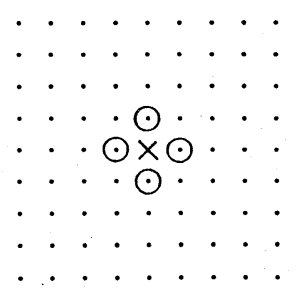

First order

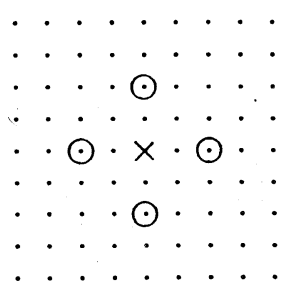

Third order

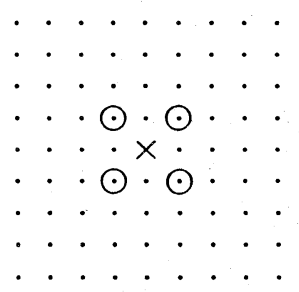

Second order
Fig. 1 Two dimensional systems
ける. 場所 $i$, 時刻 $t$ における観測值を $z_{i}(t)$ とし, 空間 時系列モデルを定式化するために，時間遅れ作用素 $B^{13}$ と同様に空間遅れ作用素 $L$ を次のように定義する.

$$
\begin{aligned}
L^{(0)} z_{i}(t)= & z_{i}(t) \\
L^{(u)} z_{i}(t)= & w_{i 1}{ }^{(u)} z_{1}(t)+w_{i 2}{ }^{(u)} z_{2}(t)+\cdots \\
& +w_{i N}{ }^{(u)} z_{N}(t) \\
= & \sum_{j=1}^{N} w_{i j}{ }^{(u)} z_{j}(t)
\end{aligned}
$$

ここで, $u$ は空間遅れを表わす次数， $N$ は観測場所の 数を表わす. また, $w_{i j}{ }^{(u)}$ は, 場所 $i$ に対して, そこか ら空間的に $u$ 次遅れた場所 $j$ から得られる依存度を示 す重み係数で次の性質を持っている.

1） $i$ 亡 $j$ の間の空間遅れ次数が $u$ 次の場合のみ零で ない值を取る。

2) $\sum_{j=1}^{N} w_{i j}{ }^{(u)}=1$

すなわち, 空間遅れ作用素 $L^{(u)}$ は場所 $i$ とそこから空 間的に $u$ 次離れた場所群からの依存度を重み係数の線 形和で表わすようにしたものである。乙れらを次のよう にベクトル表示する.

観測値ベクトル $; z(t)=\left[\begin{array}{llll}z_{1}(t) & z_{2}(t) & \cdots & z_{N}(t)\end{array}\right]^{T}$ 白色雑音ベクトル ; $\boldsymbol{e}(t)=\left[\begin{array}{llll}e_{1}(t) & e_{2}(t) & \cdots & e_{N}(t)\end{array}\right]^{T}$

$$
\begin{aligned}
& L^{(0)} \boldsymbol{Z}(t)=W^{(0)} \boldsymbol{Z}(t)=\boldsymbol{I}_{N} \boldsymbol{Z}(t) \\
& L^{(u)} \boldsymbol{Z}(t)=W^{(u)} \boldsymbol{Z}(t) \\
& =\left[\begin{array}{cccc}
w_{11}{ }^{(u)} & w_{12}{ }^{(u)} & \cdots & w_{1 N}{ }^{(u)} \\
w_{21}{ }^{(u)} & w_{22}{ }^{(u)} & \cdots & w_{2 N}{ }^{(u)} \\
\vdots & \vdots & & \vdots \\
w_{N 1}{ }^{(u)} & w_{N 2}{ }^{(u)} & \cdots & w_{N N}{ }^{(u)}
\end{array}\right]\left[\begin{array}{c}
z_{1}(t) \\
z_{2}(t) \\
\vdots \\
z_{N}(t)
\end{array}\right]
\end{aligned}
$$

ここで， $\boldsymbol{I}_{N}$ は単位行列，“ $T$ ” は転置を表わす．空間遅 れ次数 $u$ の重み係数 $w_{i j}{ }^{(u)}$ は, 隣接している場所間の 共通領域の長さや空間的に $u$ 次離れている場所 $i, j の$ 中心間の距離, 山や川なよ゙の自然の障壁, 風などの気象 条件, さらに交通網のような場所間の輸送の容易性なよ゙ の物理的特性を精度よく反映するように決定する. 同じ 空間遅れ次数のすべての場所に対して均等に重みが付け られると仮定される場合には，次に示す簡単な均等重み 係数が用いられる.

$$
w_{i j}{ }^{(u)}= \begin{cases}1 / n_{i}{ }^{(u)} & \text { 空間遅れ } u \text { 次の場合 } \\ 0 & \text { その他の場合 }\end{cases}
$$

ここで, $n_{i}{ }^{(u)}$ は $i$ から空間的に $u$ 次離れている場所の 数である.

\section{2 空間時間自己回帰 (STAR) モデル}

2.1の表記法を用いると, 空間時間自己回帰モデル (Space-Time Autoregressive Model, 以後, STAR 
モデルと呼ぶ）は次式で与えられる

$$
\boldsymbol{Z}(t)=\sum_{k=1}^{p} \sum_{u=0}^{h_{k}} \phi_{k u} W^{(u)} \boldsymbol{Z}(t-k)+\boldsymbol{e}(t)
$$

ただし，

$$
\begin{aligned}
& E[\boldsymbol{e}(t)]=\mathbf{0} \\
& E\left[\boldsymbol{e}(t) \boldsymbol{e}(t+s)^{T}\right]=\left\{\begin{array}{cc}
\sigma_{e}^{2} I_{N} & s=0 \text { のとき } \\
O & s \neq 0 \text { のとき }
\end{array}\right.
\end{aligned}
$$

である. ここに，０は零ベクトル， $O$ は零マトリックス を示す．また， $h_{k}$ は $k$ 次の自己回帰項における空間次 数を表わす.

\section{3 空間時間自己相関関数と空間時間偏自己 相関関数}

空間遅れ次数 $u$ と $v$, 時間遅れ次数 $s$ の共分散とは, ある場所 $i$ から空間的に $u$ 次離れた場所群の重み付け られた系列 $\left\{L^{(u)} z_{i}(t), t=1,2, \cdots, M ; M\right.$ はデー夕長 $\}$ 之同じ場所 $i$ から空間的に $v$ 次離れた場所群の時間遅れ $s$ を持つ重み付けられた系列 $\left\{L^{(v)} z_{i}(t+s), t=1,2, \cdots\right.$, $M-s\}$ の間の共分散を意味し，乙れらの共分散をすべ ての場所について平均したものを空間時間共分散関数 $\gamma_{u v}(s)$ と言い,

$$
\begin{aligned}
\gamma_{u v}(s) & =E\left[\sum_{i=1}^{N} \frac{L^{(u)} z_{i}(t) \cdot L^{(v)} z_{i}(t+s)}{N}\right] \\
& =E\left[\frac{\left[W^{(u)} \boldsymbol{Z}(t)\right]^{T}\left[W^{(v)} \boldsymbol{Z}(t+s)\right]}{N}\right] \\
& =\operatorname{tr}\left\{\frac{W^{(v)} W^{(u)} \Gamma(s)}{N}\right\}
\end{aligned}
$$

で表わされる.乙こで, $E\left[z_{i}(t)\right]=0(i=1,2, \cdots, N)$ とし, $\Gamma(s)=E\left[\boldsymbol{Z}(t) \boldsymbol{Z}(t+s)^{T}\right]$ である. $\Gamma(s)$ の推定 値 $\hat{\Gamma}(s)$ は,

$$
\hat{\Gamma}(s)=\frac{1}{M-s} \sum_{t=1}^{M-s} \boldsymbol{Z}(t) \boldsymbol{Z}(t+s)^{T}
$$

から得られるので，(4) 式で示される空間時間共分散関 数の推定值 $\hat{\gamma}_{u v}(s)$ は次式より計算される.

$$
\begin{aligned}
\hat{\gamma}_{u v}(s)= & \frac{1}{N(M-s)} \sum_{i=1}^{N} \sum_{t=1}^{M-s} \\
& \left\{\sum_{j=1}^{N} w_{i j}{ }^{(u)} z_{j}(t) \sum_{j=1}^{N} w_{i j}{ }^{(v)} z_{j}(t+s)\right\}
\end{aligned}
$$

以上述べた空間時間自己共分散関数を用いると, 空 間的に $u$ 次離れた場所群と空間的に $v$ 次離れた場所群 の，かつ時間遅れが $s$ である空間時間自己相関関数 (Space-time autocorrelation function) $\rho_{u v}(s)$ の推 定値 $\hat{\rho}_{u v}(s)$ は

$$
\hat{\rho}_{u v}(s)=\frac{\gamma_{u v}(s)}{\sqrt{\gamma_{u u}(0) \gamma_{v v}(0)}}
$$

から計算される.乙こで,

$$
\begin{aligned}
& \hat{\gamma}_{u v}(s) \\
& =\sum_{i=1}^{N} \sum_{t=1}^{M-s}\left\{\sum_{j=1}^{N} w_{i j}{ }^{(u)} z_{j}(t)\right\}\left\{\sum_{j=1}^{N} w_{i j}{ }^{(v)} z_{j}(t+s)\right\} \\
& \hat{\gamma}_{u u}(0)=\sum_{i=1}^{N} \sum_{t=1}^{M}\left\{\sum_{j=1}^{N} w_{i j}{ }^{(u)} z_{j}(t)\right\}^{2} \\
& \hat{\gamma}_{v v}(0)=\sum_{i=1}^{N} \sum_{t=1}^{M}\left\{\sum_{j=1}^{N} w_{i j}{ }^{(v)} z_{j}(t)\right\}^{2}
\end{aligned}
$$

である.しかし，一般的には片方の空間次数を固定して 考えればよく，したがって， $v=0$ とすると， $\rho_{u}(s)=$ $\rho_{u 0}(s)$ となり, 乙の推定值 $\rho_{u}(s)$ は次式より得られる.

$$
\hat{\rho}_{u}(s)=\frac{\sum_{i=1}^{N} \sum_{t=1}^{M-s}\left\{\sum_{j=1}^{N} w_{i j}{ }^{(u)} z_{j}(t)\right\} z_{i}(t+s)}{\sqrt{\sum_{i=1}^{N} \sum_{t=1}^{M}\left\{\sum_{j=1}^{N} w_{i j}{ }^{(u)} z_{j}(t)\right\}^{2} \sum_{i=1}^{N} \sum_{t=1}^{M} z_{i}(t)^{2}}}
$$

ここで, STAR モデル

$$
\boldsymbol{Z}(t)=\sum_{k=1}^{p} \sum_{u=0}^{h_{k}} \phi_{k u} W^{(u)} \boldsymbol{Z}(t-k)+\boldsymbol{e}(t)
$$

の両辺に $\left[W^{(r)} \boldsymbol{Z}(t-s)\right]^{T}$ を左から掛けた後, 両辺を $N$ で割って期待值をとり,

$$
\begin{aligned}
& E\left[\frac{\left[W^{(r)} \boldsymbol{Z}(t-s)\right]^{T} \boldsymbol{Z}(t)}{N}\right]=\gamma_{r 0}(s) \\
& E\left[\frac{\left[W^{(r)} \boldsymbol{Z}(t-s)\right]^{T} W^{(u)} \boldsymbol{Z}(t-k)}{N}\right]=\gamma_{r u}(s-k) \\
& E\left[\frac{\left[W^{(r)} \boldsymbol{Z}(t-s)\right]^{T} \boldsymbol{e}(t)}{N}\right]=0
\end{aligned}
$$

の関係を用いると

$$
\gamma_{r 0}(s)=\sum_{k=1}^{p} \sum_{u=0}^{h_{k}} \phi_{k u} \gamma_{r u}(s-k)
$$

が得られる. こてで, $s=1,2, \cdots, p, r=0,1,2, \cdots, h_{k}$ である. この式は空間時系列に対するYule-Walker 方 程式であり， $u=0,1,2, \cdots, h_{k}, p=1,2, \cdots$ 亿対する 連立方程式を解くことによって得られた最終項 $\phi_{k u}$ が時 間遅れ $k$, 空間遅れ $u$ の空間時間偏自己相関関数となる.

\section{3. 時系列データのモデリング}

\section{1 空間時系列モデルによるモデリング}

空間時間自己相関関数と空間時間偏自己相関関数は空 間時間時系列に対して，時間遅れ，空間遅れが大きくな るにともなって，それぞれの関数の形状が tail off また は cut off のいずれかに分類されるという特徴を持って いる ${ }^{9 \sim 11}$. したがって, 取得された時系列データよりて れらの関数を計算し，それらの形状の特徵から同定すべ きモデルの型を決定することができる. cut off の場合 
は，時間的および空間的に cut off されていると見なさ れる遅れの大きさを調べるてとによってモデルの次数を 決定する. モデルの型と次数が決定されると次はパラメー 夕を推定するてとになる。 その方法として, 基本的には, 最小二乗法により得られたパラメータの初期推定值をむ とに, 最尤推定法により順次精度の高いパラメータを求 めていく方法が一般的に用いられている.さらに, あて はめたモデルの妥当性を調べるための検定を行なうこと によって，モデリングが終了する. 時系列が STAR モ デルに同定された場合は, データから計算された空間時 間自己相関関数の推定值 $\hat{\gamma}_{r u}(s)$ とパラメータの線形結 合よりなる Yule-Walker 方程式

$$
\hat{\gamma}_{r 0}(s)=\sum_{k=1}^{p} \sum_{u=0}^{h_{k}} \phi_{k u} \hat{\gamma}_{r u}(s-k)
$$

を解くことによって, パラメータの初期推定值 $\phi_{k u}$ が得 られる. こてで, $s=1,2, \cdots, p, r=0,1,2, \cdots, h_{k}$ で ある. このようにして得られた初期推定值は, デー夕数 $M$ が十分大きい場合には, 漸近的に最尤推定值になる. 本研究では, 実測データにあてはめられるモデル が STAR モデルとなるため, 最尤推定法を用いず, (10) 式から得ら机る解をモデルのパラメータとする. てのモデルにあてはめる時, 推定すべきパラメータの 個数は $p+h_{1}+h_{2}+\cdots+h_{p}$ 個の自己回帰パラメー夕と $N \times N$ （空間遅れ次数の最大值）個の重み係数となる. ただし, 空間重み係数を変更する必要のない場合は, 一 度決定して打けばモデリングの際にその都度それを变更 する必要がない.また, 空間遅れ次数之空間重み係数は, 考察領域の観測地点の個数扔よび位置関係などを考慮し て, 時系列のモデリングの前に決められるので, 空間遅 れ次数の最大値はその処理より明らかになる. 当然, $h_{1}, h_{2}, \cdots, h_{p}$ の最大值は空間遅れ次数の最大值より小 さくなる. したがって, 常時, 推定しなければならない パラメータは, $p+h_{1}+h_{2}+\cdots+h_{p}$ 個の自己回帰パラメ 一タのみとなる.

\section{2 通常の時系列モデルによるモデリング}

空間時系列モデルによる予測精度の検討のために, 従 来の時間遅れのみを考慮した時系列モデルによる予測を 行なう必要がある。 そこで, 個々の観測点で取得された 時系列データに観測点ごとに独立に 1 次元の自己回帰モ デルをあてはめ, $N$ 個の 1 次元自己回帰モデルを作る. また, 時刻 $t$ に扔いて $N$ 個の観測点で同時に取得され たデータを $N$ 次元の観測值ベクトル $\boldsymbol{Z}(t)$ とし, $M$ 個 のベクトルよりなる多次元時系列データ $\{\boldsymbol{Z}(t), t=1$, $2, \cdots, M\}$ 亿対して次の $N$ 次元自己回帰モデルをああ てはめる.

$$
\boldsymbol{Z}(t)=\sum_{j=1}^{p} A_{j} \boldsymbol{Z}(t-j)+\boldsymbol{e}(t)
$$

ここで, $p$ は自己回帰項の次数, $A_{j}$ は $N \times N$ の自己 回帰パラメータよりなる行列である. したがって, 推定 すべきパラメータ数は $N \times N \times p$ となる．な抒， $N=1$ のときは，1次元の自己回帰モデルとなる. 乙れらのモ デリングの際には，FPE 法や AIC 法を使用することが できる ${ }^{9,14,15}$.

\section{4. 大気污染質レベル值の空間時系列モデル へのあてはめ}

こてでは, 1979 年 9 月と 10 月の 2 か月間に Fig. 2 亿 示す徳島県東部の 7 か所で 1 時間でとに観測された OX 濃度レベル值からなる時系列を空間時系列として取り扱 い，それに空間時系列モデルをあてはめる．モデリング の際, 空間遅れ次数と重み係数の決定方法は非常に重要 であり, 大気污染質レベル值の予測問題では, 観測場所 間の位置関係や観測場所間の污染質レベル值の相互関係 などの物理特性を精度よく反映するように決定しなけれ ばならない，本論文では，従来の時系列モデルでは考慮 することが出来なかったてれらの情報を取り入れた空間 時系列モデルの作成法を提案する. さらに, 風向きが予 測精度に影響を与えることを考慮し, 風向きから重みマ トリックスを決定し, 空間時系列モデルを構成する手法 あ合わせて提案する.

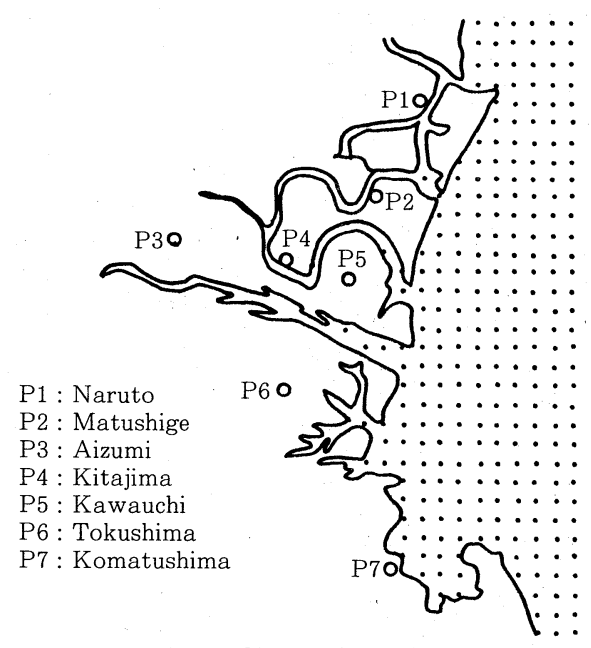

Fig. 2 Observation points

\section{1 重みマトリックスの作成}

Fig. 2 亿示された 7 か所の観測場所の位置関係を考 慮して空間遅れ次数を Table 1 亿示すように決定し, それを用いて重みマトリックスを作成する．その簡単な 方法としては, 空間遅れ次数が同じである場所群には均 
Table 1 The relation between observation points and spatial lag order

\begin{tabular}{|c|c|c|c|c|}
\hline $\begin{array}{c}\text { Spatial } \\
\text { lag } \\
\text { order }\end{array}$ & $\begin{array}{l}\text { Point group } \\
\text { with first } \\
\text { spatial lag } \\
\text { order }\end{array}$ & $\begin{array}{l}\text { Point group } \\
\text { with second } \\
\text { spatial lag } \\
\text { order }\end{array}$ & $\begin{array}{l}\text { Point group } \\
\text { with third } \\
\text { spatial lag } \\
\text { order }\end{array}$ & $\begin{array}{l}\text { Point group } \\
\text { with fourth } \\
\text { spatial lag } \\
\text { order }\end{array}$ \\
\hline Naruto & Matushige & $\begin{array}{l}\text { Kitajima } \\
\text { Kawauchi }\end{array}$ & $\begin{array}{l}\text { Aizumi } \\
\text { Tokushima }\end{array}$ & Komatushima \\
\hline Matushige & $\begin{array}{l}\text { Naruto } \\
\text { Kitajima } \\
\text { Kawauchi }\end{array}$ & $\begin{array}{l}\text { Aizumi } \\
\text { Tokushima }\end{array}$ & Komatushima & \\
\hline Aizumi & Kitaj̣ima & $\begin{array}{l}\text { Matushige } \\
\text { Kawauchi } \\
\text { Tokushima }\end{array}$ & $\begin{array}{l}\text { Naruto } \\
\text { Komatushima }\end{array}$ & \\
\hline Kitajima & $\begin{array}{l}\text { Matushige } \\
\text { Aizumi } \\
\text { Kawauchi } \\
\text { Tokushima }\end{array}$ & $\begin{array}{l}\text { Naruto } \\
\text { Komatushima }\end{array}$ & & \\
\hline Kawauchi & $\begin{array}{l}\text { Matushige } \\
\text { Kitajima } \\
\text { Tokushima }\end{array}$ & $\begin{array}{l}\text { Naruto } \\
\text { Aizumi } \\
\text { Komatushima }\end{array}$ & & \\
\hline Tokushima & $\begin{array}{l}\text { Kitajima } \\
\text { Kawauchi } \\
\text { Komatushima }\end{array}$ & $\begin{array}{l}\text { Matushige } \\
\text { Aizumi }\end{array}$ & Naruto & \\
\hline Komatushima & Tokushima & $\begin{array}{l}\text { Kitajima } \\
\text { Kawauchi }\end{array}$ & $\begin{array}{l}\text { Matushige } \\
\text { Aizumi }\end{array}$ & Naruto \\
\hline
\end{tabular}

等な重みをつける均等重みマトリッ クス法が用いられる場合が多く, Fig. 3 にその場合の重みマトリックスを示す. しかし，この重みマトリックスは，観測 場所間の距離に関する情報は取り込んで いるが，污染質レベル值の観測場所間の 相互関係に関する情報を取り入れていな い. そこで, 距離情報と共にこの関係を 考虑するために, 本研究では, 各々の観 測場所で取得されたデータから場所間の 相関係数を計算し，その比から重みマト リックスを決める方法を新しく用いる. まず，7 か所の観測場所において予測を 行なう日の前日までの 1 か月間に観測さ れたデータから，各観測場所の污染質レ ベル值間の相関行列を求める.つぎに, ある観測場所に注目すると, Table 1 に 示す観測場所と空間遅れ次数との関係に 基づいて，その場所と同じ空間遅れ次数 を持つ観測場所群を選ぶ. そして, 注目 している場所とてれらの観測場所間の相 関係数を用い，2.1で述べた重み係数が

\begin{tabular}{|c|c|c|c|c|c|c|c|}
\hline & P1 & P2 & P3 & P4 & P5 & P6 & P7 \\
\hline P1 & 0 & 1 & 0 & 0 & 0 & 0 & 1 \\
\hline P2 & 0.33 & 0 & 0 & 0.33 & 0.33 & 0 & 0 \\
\hline P3 & 0 & 0 & 0 & 1 & 0 & 0 & 0 \\
\hline P4 & 0 & 0.25 & 0.25 & 0 & 0.25 & 0.25 & 0 \\
\hline P5 & 0 & 0.33 & 0 & 0.33 & 0 & 0.33 & 0 \\
\hline P6 & 0 & 0 & 0 & 0.33 & 0.33 & 0 & 0.33 \\
\hline P7 & 1 & 0 & 0 & 0 & 0 & 1 & 0 \\
\hline
\end{tabular}

(a) First order weighting matrix

\begin{tabular}{|c|c|c|c|c|c|c|c|}
\hline & P1 & P2 & P3 & P4 & P5 & P6 & P7 \\
\hline $\mathrm{P} 1$ & 0 & 0 & 0 & 0.5 & 0.5 & 0 & 1 \\
\hline P2 & 0 & 0 & 0.5 & 0 & 0 & 0.5 & 0 \\
\hline P3 & 0 & 0.33 & 0 & 0 & 0.33 & 0.33 & 0 \\
\hline P4 & 0.5 & 0 & 0 & 0 & 0 & 0 & 0.5 \\
\hline P5 & 0.33 & 0 & 0.33 & 0 & 0 & 0 & 0.33 \\
\hline P6 & 0 & 0.5 & 0.5 & 0 & 0 & 0 & 0 \\
\hline P7 & 0 & 0 & 0 & 0.5 & 0.5 & 0 & 0 \\
\hline
\end{tabular}

(b) Second order weighting matrix

\begin{tabular}{|c|c|c|c|c|c|c|c|}
\hline & P1 & P2 & P3 & P4 & P5 & P6 & P7 \\
\hline P1 & 0 & 0 & 0.5 & 0 & 0 & 0.5 & 0 \\
\hline P2 & 0 & 0 & 0. & 0 & 0 & 0 & 1 \\
\hline P3 & 0.5 & 0 & 0 & 0 & 0 & 0 & 0.5 \\
\hline P4 & 0 & 0 & 0 & 0 & 0 & 0 & 0 \\
\hline P5 & 0 & 0 & 0 & 0 & 0 & 0 & 0 \\
\hline P6 & 1 & 0 & 0 & 0 & 0 & 0 & 0 \\
\hline P7 & 0 & 0.5 & 0.5 & 0 & 0 & 0 & 0 \\
\hline
\end{tabular}

(c) Third order weighting matrix

\begin{tabular}{|c|c|c|c|c|c|c|c|}
\hline & P1 & P2 & P3 & P4 & P5 & P6 & P7 \\
\hline P1 & 0 & 0 & 0 . & 0 & 0 & 0 & 1 \\
\hline P2 & 0 & 0 & 0 & 0 & 0 & 0 & 0 \\
\hline P3 & 0 & 0 & 0 & 0 & 0 & 0 & 0 \\
\hline P4 & 0 & 0 & 0 & 0 & 0 & 0 & 0 \\
\hline P5 & 0 & 0 & 0 & 0 & 0 & 0 & 0 \\
\hline P6 & 0 & 0 & 0 & 0 & 0 & 0 & 0 \\
\hline P7 & 1 & 0 & 0 & 0 & 0 & 0 & 0 \\
\hline
\end{tabular}

(d) Fourth order weighting matrix

Fig. 3 Equal scaled weighting matrix
持つ性質を満足し，しかも各観測場所の重み係数が観測 場所間の相関係数の比になるように重み係数を決定する.

例として，松茂 (Matushige) に注目した場合を考え る。松茂と空間的に 1 次離れている場所群は鳴門 (Naruto), 北島 (Kitajima), 川内 (Kawauti)の 3 か 所となっており，松茂に対する鳴門，北島，および川内 の相関係数がそれぞれ $c_{1}, c_{2}, c_{3}$ のときには, 1 次の重み マトリックス内の松茂に対する鳴門，北島，川内の重み 係数をそれぞれ， $c_{1} /\left(c_{1}+c_{2}+c_{3}\right), c_{2} /\left(c_{1}+c_{2}+c_{3}\right), c_{3} /$ $\left(c_{1}+c_{2}+c_{3}\right)$ にすればよい. 乙てで使用した OX データ に関しては，各観測場所間の相互相関係数が非常に大き く，しか屯よく似た大きさであったので，乙の方法で求 めた重みマトリックスは, 均等重みマトリックスとよく 似たものになっている.

ところで，大気の污染状態は風の影響を非常に受ける ので, 高い精度の予測を行なうためには時系列モデルの 中に風向きの情報を取り入れることが必要であり,さら に風向きは時刻ととあに变化するので, 時変系のモデル にすることが望ましい，そこで，風向きの情報を重みマ トリックスに取り込み，その重みマトリックスを時刻に よって変えるととによって時変系のモデルを構成する方 法を考察する. 風向き, 風速のデータは 1 時間でとに得 られて招り，風向きは16方位に分けられている.しか し，乙れをそのまま空間時系列モデルに取り入れること は難しいので, 本研究では次のような簡単な方法を採用 
Table 2 Cross-correlation matrix computed from OX data of August classfied by wind direction

(a) In case of north wind direction

\begin{tabular}{|c|c|c|c|c|c|c|c|}
\hline Point & P 1 & P 2 & P 3 & P 4 & P 5 & P 6 & P 7 \\
\hline P 1 & 1.000 & 0.948 & 0.848 & 0.869 & 0.871 & 0.847 & 0.825 \\
\hline P 2 & 0.948 & 1.000 & 0.898 & 0.909 & 0.912 & 0.893 & 0.863 \\
\hline P 3 & 0.848 & 0.893 & 1.000 & 0.936 & 0.903 & 0.918 & 0.900 \\
\hline P 4 & 0.869 & 0.909 & 0.936 & 1.000 & 0.914 & 0.922 & 0.882 \\
\hline P 5 & 0.871 & 0.912 & 0.903 & 0.914 & 1.000 & 0.908 & 0.889 \\
\hline P 6 & 0.847 & 0.893 & 0.918 & 0.922 & 0.908 & 1.000 & 0.937 \\
\hline P 7 & 0.825 & 0.863 & 0.900 & 0.882 & 0.889 & 0.937 & 1.000 \\
\hline
\end{tabular}

P1: Naruto P2: Matushige P3 : Aizumi P4: Kitajima P5 : Kawauchi P6: Tokushina P7 : Komatushina

(b) In case of west wind direction

\begin{tabular}{|c|c|c|c|c|c|c|c|}
\hline Point & P 1 & P 2 & P 3 & P 4 & P 5 & P 6 & P 7 \\
\hline P 1 & 1.000 & 0.793 & 0.625 & 0.582 & 0.604 & 0.595 & 0.664 \\
\hline P 2 & 0.793 & 1.000 & 0.774 & 0.737 & 0.835 & 0.677 & 0.747 \\
\hline P 3 & 0.625 & 0.774 & 1.000 & 0.789 & 0.789 & 0.681 & 0.708 \\
\hline P 4 & 0.582 & 0.737 & 0.789 & 1.000 & 0.860 & 0.782 & 0.705 \\
\hline P 5 & 0.604 & 0.835 & 0.789 & 0.860 & 1.000 & 0.770 & 0.751 \\
\hline P 6 & 0.595 & 0.677 & 0.681 & 0.782 & 0.770 & 1.000 & 0.803 \\
\hline P 7 & 0.664 & 0.747 & 0.708 & 0.705 & 0.751 & 0.803 & 1.000 \\
\hline
\end{tabular}

P1: Naruto P2: Matushige P3 : Aizumi P4: Kitajima P5 : Kawauchi P6 : Tokushima P7: Komatushima

する．まず，各時刻に打ける風向き，風速をべクトルで 表わし，モデリングに使用する 1 か月のデータから各時 刻の平均風向きと風速を計算し，風向きを東西南北の 4 方向に分類する. ててで用いた 9 月のデータに関しては, ほとんどの場所で 10 時から 18 時までが北風，1時から 9 時までおよび 19 時から 24 時までが西風という結果が 得られている. 北風の期間抢よび西風の期間の $\mathrm{OX}$ デ ータより計算した各観測場所間の相関行列をそれぞれ Table 2 (a), (b) 飞示す. 前述の方法を用い, これら の相関係数に基づいて作成した北風之西風の時の重みマ トリックスをそれぞれ Fig. 4, Fig. 5 に示す.

\section{2 同定およびパラメー夕推定}

大気污染質データは, 一般に 24 時間 1 周期の周期性 を持つ非定常時系列であるが，本研究で取り扱うモデル にあてはめるためには，時系列は定常でなりればならな い. 非定常時系列より非定常成分を除去して定常時系列

P1
P2
P3 $\left[\begin{array}{lllllll}0 & \text { P2 } & \text { P3 } & \text { P4 } & \text { P5 } & \text { P6 } & \text { P7 } \\ \text { P4 } & 0 & 0 & 0 & 0 & 0 \\ \text { P'5 } & 0 & 0 & 0.33 & 0.33 & 0 & 0 \\ \text { P6 } & 0 & 0 & 1 & 0 & 0 & 0 \\ \text { P7 } & 0.25 & 0.25 & 0 & 0.25 & 0.25 & 0 \\ 0 & 0.33 & 0 & 0.34 & 0 & 0.33 & 0 \\ 0 & 0 & 0 & 0.33 & 0.33 & 0 & 0.34 \\ 0 & 0 & 0 & 0 & 0 & 1 & 0\end{array}\right]$

(a) First order weighting matrix

\begin{tabular}{|c|c|c|c|c|c|c|c|}
\hline & P1 & P2 & P3 & P4 & P5 & P6 & P7 \\
\hline P1 & 0 & 0 & 0 & 0.5 & 0.5 & 0 & 0 \\
\hline P2 & 0 & 0 & 0.5 & 0 & 0 & 0.5 & 0 \\
\hline P3 & 0 & 0.33 & 0 & 0 & 0.33 & 0.34 & 0 \\
\hline P4 & 1 & 0 & 0 & 0 & 0 & 0 & 0 \\
\hline P5 & 0.33 & 0 & 0.34 & 0 & 0 & 0 & 0.33 \\
\hline P6 & 0 & 0.49 & 0.51 & 0.49 & 0.51 & 0 & 0 \\
\hline P7 & 0 & 0 & 0 & 0 & 0 & 0 & 0 \\
\hline
\end{tabular}

(b) Second order weighting matrix

\begin{tabular}{|c|c|c|c|c|c|c|c|}
\hline & P1 & P2 & P3 & P4 & P5 & P6 & P7 \\
\hline $\mathrm{P} 1$ & 0 & 0 & 0.5 & 0 & 0 & 0.5 & 0 \\
\hline P2 & 0 & 0 & 0 & 0 & 0 & 0 & 1 \\
\hline P3 & 0.49 & 0 & 0 & 0 & 0 & 0 & 0.51 \\
\hline P4 & 0 & 0 & 0 & 0 & 0 & 0 & 0 \\
\hline P5 & 0 & 0 & 0 & 0 & 0 & 0 & 0 \\
\hline P6 & 1 & 0 & 0 & 0 & 0 & 0 & 0 \\
\hline P7 & 0 & 0.49 & 0.51 & 0 & 0 & 0 & 0 \\
\hline
\end{tabular}

(c) Third order xeighting matrix

\begin{tabular}{|c|c|c|c|c|c|c|c|}
\hline & P1 & P2 & P3 & P4 & P5 & P6 & P7 \\
\hline P1 & 0 & 0 & 0 & 0 & 0 & 0 & 1 \\
\hline P2 & 0 & 0 & 0 & 0 & 0 & 0 & 0 \\
\hline P3 & 0 & 0 & 0 & 0 & 0 & 0 & 0 \\
\hline P4 & 0 & 0 & 0 & 0 & 0 & 0 & 0 \\
\hline P5 & 0 & 0 & 0 & 0 & 0 & 0 & 0 \\
\hline P6 & 0 & 0 & 0 & 0 & 0 & 0 & 0 \\
\hline P7 & 1 & 0 & 0 & 0 & 0 & 0 & 0 \\
\hline
\end{tabular}

(d) Forth order weighting matrix

Fig. 4 Weighting matrix based on coefficient of correlation in case of north wind direction

を作る前処理方法は多く提案されているが ${ }^{1 \sim 3}$, こてで は最む簡単な方法，すなわち，1 時間でとに観測された データから各時刻の 1 か月間の平均值を求め, あとのデ 一夕より対応する時刻の平均值を差し引くという前処理 を行なう. 9 月 1 か月間の OX データについてての前処 理を行なった後，空間時間自己相関関数および空間時間 偏自己相関関数を計算した結果を Table 3 (a), (b) に 示す.乙れらの結果から, このデータに関しては, 空間 時間自己相関関数は時間遅れ, 空間時間遅れと屯に tail off しており，また空間時間偏自己相関関数については, 時間遅れ 2 次の後また空間遅れ 2 次の後 cut off してい ると見ることができる. したがって, 同定されるモデル として STAR $\left(2_{22}\right)$ が適当になり，乙のモデルに対す る Yule-Walker 方程式を解くことによってパラメータ の推定值が得られる. 均等マトリックスを用いた場合, このデータに対するパラメータの推定值は次のようにな る.

$$
\begin{array}{lll}
\phi_{10}=0.873 & \phi_{11}=0.220 & \phi_{12}=0.243 \\
\phi_{20}=-0.112 & \phi_{21}=-0.166 & \phi_{22}=-0.153
\end{array}
$$




P1 1 P2
P2

(a) First order weighting matrix

\begin{tabular}{|c|c|c|c|c|c|c|c|}
\hline & P1 & P2 & P3 & P4 & P5 & P6 & P7 \\
\hline P1 & 0 & 0 & 0 & 0.49 & 0.51 & 0 & 0 \\
\hline P2 & 0 & 0 & 0.53 & 0 & 0 . & 0.47 & 0 \\
\hline P3 & 0 & 0.35 & 0 & 0 & 0.35 & 0.3 & 0 \\
\hline P4 & 1 & 0 & 0 & 0 & 0 & 0 & 0 \\
\hline P5 & 0.28 & 0 & 0.37 & 0 & 0 & 0 & 0.35 \\
\hline P6 & 0 & 0.5 & 0.5 & 0 & 0 & 0 & 0 \\
\hline P7 & 0 & 0 & 0 & 0.5 & 0.5 & 0 & 0 \\
\hline
\end{tabular}

(b) Second order weighting matrix

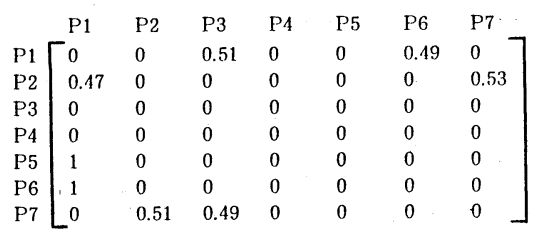

(c) Third order weighting matrix

\begin{tabular}{|c|c|c|c|c|c|c|c|}
\hline & P1 & P2 & P3 & P4 & P5 & P6 & P7 \\
\hline P1 & 0 & 0 & 0 & 0 & 0 & 0 & 1 \\
\hline P2 & 0 & 0 & 0 & 0 & 0 & 0 & 0 \\
\hline P3 & 0 & 0 & 0 & 1 & 0 & 0 & 0 \\
\hline P4 & 0 & 0 & 0 & 0 & 0 & 0 & 0 \\
\hline P5 & 0 & 0 & 0 & 0 & 0 & 0 & 0 \\
\hline P6 & 0 & 0 & 0 & 0 & 0 & 0 & 0 \\
\hline P7 & 1 & 0 & 0 & 0 & 0 & 0 & 0 \\
\hline
\end{tabular}

(d) Fourth order weighting matrix

Fig. 5 Weighting matrix based on coefficient of correlation in case of west wind disection

観測場所間の相関係数に基づいた重みマトリックスを用 いた場合，および風向きを考慮した重みマトリックスを 用いた場合についても同様にしてパラメータを推定す る，な执，風向きを考慮する場合には，時刻によって風 向きが変わるため, 時刻でとの風向きに対応した重みマ トリックスを用いてモデリングを行なう必要がある. 乙 こでは，前に述べたように風向きを統計的に処理して北 風之西風の 2 方向に分けているので, 北風の時刻と西風 の時刻に分けて重みマトリックスを変えるようにしてい る．また，空間時系列モデルを用いた予測の精度検討の ため，取得された時系列に対して各観測場所ごとに 1 次 元自己回帰モデルをあてはめるととあに, 7 か所で同時 刻に観測されたデータをべクトルとして取り扱う７次元 自己回帰モデルも作成する.

\section{5. 予測結果と考察}

前述の空間時系列モデルを用いて 7 か所の観測場所に おける 10 月の OX 濃度の予測を行ない, その結果と通 常の 1 次元および 7 次元自己回帰モデルを用いた場合の
Table 3 Space-time autocorrelation function and space-time partial autocorrelation function computed from OX data of September

(a) Space-time autocorrelation function

\begin{tabular}{|c|c|c|c|c|c|}
\hline $\begin{array}{c}\text { Spatial lag } \\
\text { order } \\
\text { Time order }\end{array}$ & 0 & 1 & 2 & 3 & 4 \\
\hline 0 & 1.000 & 0.891 & 0.843 & 0.750 & 0.499 \\
\hline 1 & 0.910 & 0.838 & 0.803 & 0.725 & 0.483 \\
\hline 2 & 0.780 & 0.740 & 0.717 & 0.656 & 0.439 \\
\hline 3 & 0.764 & 0.641 & 0.626 & 0.572 & 0.384 \\
\hline 4 & 0.574 & 0.552 & 0.540 & 0.489 & 0.328 \\
\hline 5 & 0.484 & 0.470 & 0.457 & 0.480 & 0.272 \\
\hline
\end{tabular}

(b) Space-time partial autocorrelation function

\begin{tabular}{|c|c|c|c|c|c|}
\hline $\begin{array}{c}\text { Spatial lag } \\
\text { Time } \\
\text { lag order }\end{array}$ & 0 & 1 & 2 & 3 & 4 \\
\hline 1 & 0.910 & 0.136 & 0.092 & 0.056 & 0.003 \\
\hline 2 & -0.236 & -0.243 & -0.153 & -0.101 & -0.093 \\
\hline 3 & 0.021 & 0.014 & 0.023 & -0.032 & 0.025 \\
\hline 4 & -0.031 & -0.025 & -0.030 & -0.027 & 0.003 \\
\hline 5 & -0.004 & -0.019 & -0.074 & -0.033 & -0.006 \\
\hline
\end{tabular}

予測結果を比較検討する．予測する日の前日までの 30 日間のデータからてれらのモデルを作り，各場所に打け る OX 濃度レベル值の 1 時間先の予測を行なう。たと えば, 9 月 5 日から 10 月 4 日までのデータでモデルを作 り, 10 月 5 日の各時刻の濃度レベル值を予測する. Fig. 6 亿均等重みマトリックスを用いた STAR $\left(2_{22}\right)$ モデ ルによる川内の 10 月 21 日から 23 日までの 1 時間先の 予測値と実測值を示す。また，Fig. 7 亿風向きを考慮 した重みマトリックスを用いた STAR $\left(2_{22}\right)$ モデルに

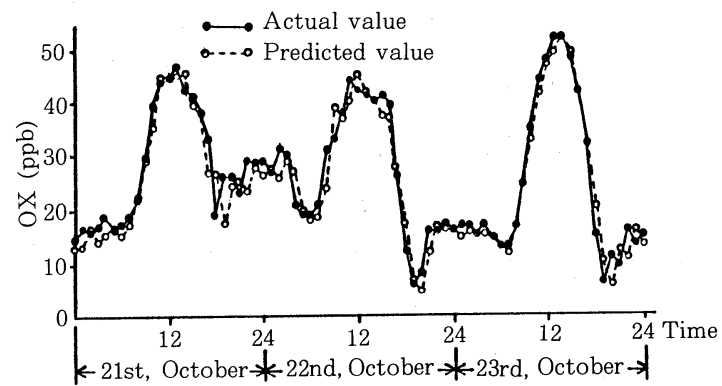

Fig. 6 The predicted values at one hour in advance by STAR $\left(2_{22}\right)$ model with equal scaled weighting matrix and actual values at Matushige 


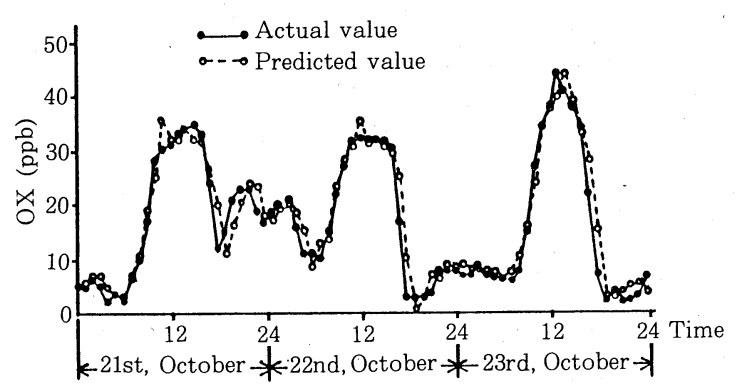

Fig. 7 The predicted values at one hour in advance by STAR $\left(2_{22}\right)$ model with weighting matrix considering wind direction and actual values at Kawauchi

よる松茂の 1 時間先の予測值と実測值を示す．乙れらの 結果は, 空間時系列モデルを用いてかなり良い精度で予 測が出来ることを表わしている.

本研究で述べた各種モデルによる予測精度の比較検討 を行なうため, つぎに示す䛊差評価規範 $J_{i}$ を各観測場 所に扔いて計算し, 予測誤差を定量化する.

$$
J_{i}=\sum_{d=1}^{31} \sum_{t=1}^{24}\left\{z_{i}(d, t)-\hat{z}_{i}(d, t)\right\}^{2} / 24
$$

ここに, $i$ は場所, $d$ は日, $t$ は時刻を表わす. すなわち, $z_{i}(d, t)$ は場所 $i$ の $d$ 日 $t$ 時の観測值, $\hat{z}_{i}(d, t)$ はその 時刻の予測值である。すべての場所において, STAR $\left(2_{22}\right)$ モデルと 1 次元および 7 次元の自己回帰モデルか ら計算された $J_{i}$ と各モデルに対するそれらの合計を Table 4 に示す. この結果から，ほとんどの場所で従来 の時系列モデルによる予測よりあ空間時系列モデルを用 いたときの予測精度が良く，しかも，風向きを考慮した 空間時系列モデルを用いた場合が最む精度良く予測でき ることが明らかになった。しかし，期待したほど予測精 度の向上が得られていない. その原因として, 簡単化の ために風向きを 4 方向にのみに分けたとと, 風の強さに

Table 4 Performance index $J_{i}$ at each observation point and their total

\begin{tabular}{|c|c|c|c|c|c|c|c|c|}
\hline Model & P1 & P2 & P3 & P4 & P5 & P6 & P7 & Total \\
\hline Model 1 & 686.8 & 785.5 & 551.1 & 587.2 & 637.4 & 560.0 & 773.1 & 4881.1 \\
\hline Model 2 & 669.3 & 777.9 & 507.2 & 534.0 & 625.0 & 551.7 & 724.4 & 4389.5 \\
\hline Model 3 & 668.3 & 689.7 & 501.8 & 526.0 & 625.1 & 531.3 & 721.9 & 4264.1 \\
\hline Model 4 & 667.6 & 689.2 & 499.5 & 525.6 & 607.8 & 530.9 & 725.2 & 4245.8 \\
\hline
\end{tabular}

P1: Naruto P2: Matushige P3: Aizumi P4: Kitajima P5 : Kawavchi P6: Tokushima P7 : Komatushima Model 1 : One dinensional AR model

Model 2 : Seven dimensional AR model

Model 3 : STAR $\left(2_{22}\right)$ model using equal scaled weighting matrix

Model 4 : STAR $\left(2_{22}\right)$ model considering wind direction
よる影響や場所間の地形的な問題などを考慮しなかった こと, さらには, 統計的処理によって風向きと時刻の対 応関係を決め, しかもその関係を固定しているため, 予 測時刻の風向きとモデルの風向きが異なる場合があるな どが考えられる. また, 観測場所間の空間遅れ次数の変 更によっても予測精度が変わるため, その次数の決定に も十分留意する必要がある. このような問題点は残って はいるが, これらの結果から, 空間時系列モデルの大気 污染質レベル值予測への適用の妥当性が確認され, さら に, 風向きを考慮した空間時系列モデルを用いた結果に 予測精度の向上が見られており，乙の方法の有効性が確 かめられている。

\section{6. むすび}

本論文では，空間的に広く関連していると考えられる 大気污染質レベル値に対して, 空間時間時系列モデルを 用いてその短期予測を試みた. 空間時系列モデルには従 来の時間遅れのみを考慮した時系列モデルにはなかった 空間遅れという概念が取り入れられており, 空間重みマ トリックスを用いて各観測場所間の相互依存性を考慮出 来るようにモデルが構成されている. 本研究では，乙の マトリックスの決定方法として, 従来から用いられてき た均等重みマトリックスのほかに, 各場所間の相互相関 を考慮して決める重みマトリックスを新しく用いた. 特 に，時刻により風向きが変化することに注目し，風向き により変更可能な重みマトリックスを作成する方法を提 案して，風向きの影響を空間時系列モデルに取り入れる ことを可能にした. 数值例として, 徳島県東部の 7 か所 で観測されたデータに対して, 空間時系列モデルと従来 の時系列モデルを用いた場合の予測精度を比較検討した. その結果，空間時系列モデルの大気污染質レベル值予測 への適用の妥当性が確認され, 本モデルが大気污染質レ ベル值予測問題に大きな手段になるあの と思われる. 今後, 風向きの取り扱いを 再検討するとともに，風向き以外の気象 条件を考慮した空間時系列モデルを構成 し，実データに適用するてとによって， その予測能力を検証する予定である.

\section{参 考 文 献}

1) Y. Sawaragi, T. Soeda, T. Yoshimura, S. Oe, Y. Chujo \& H. Ishihara : The Prediction of Air Pollution Levels by Nonphysical Models Based on Kalman Filtering Method; Trans. ASME Series G, Vol. 98, No. 4, pp. 375 386 (1976)

2) Y.Sawaragi, T. Soeda, T. Tamura, T. Yoshimura, S. Oe, Y. Chujo \& H. 
Ishihara : Statistical Prediction of Air Pollution Levels Using Nonphysical Models ; Automatica, Vol. 15, No. 4, pp. 375 386 (1979)

3) 大恵, 添田 : 大気污染質データの前処理と自己回帰モデル による短期予測 ; 德島大学工学部研究報告, 23 巻, pp. 9 $20(1977)$

4) 松本, 広崎, 進藤, 間島, 渡辺: 光化学オキシダントの広 域移流現象における統計モデル；第 27 回大気污染学会講 演要旨集, p. 275 (1986)

5) H. Tamura \& T. Kondo : Large-Spatial Pattern Identification of Air Pollution by a Combined Model of Source-Receptor Matrix and Revised GMDH ; IFAC Symposium on Environmental Systems Planning, Design and Control, Kyoto, pp. 373 380 (1977)

6) 井上, 星, 田栗, 浅井, 多賀: NOx 濃度 (1 時間值) デ 一夕に関する統計的解析; 文部省「環境科学」特別研究研 究報告書 $(B-165-R-53-2)$, pp. 80〜93 (1983)

7) 樋口, 柳本, 尾崎: 一般大気環境に対する固定監視システ ムの観測データの統計的観察; 文部省「環境科学」特別研 究研究報告書 $(B-165-R-53-2), p p .94$ 104 (1983)

8) R. J. Bennett : Spatial Time Series, Pilon Limited (1979)

9) 赤池, 中川: ダイナミックシステムの統計的解析と制御, サイエンス社 (1972)

10). P. E. Pfeifer \& S. J. Deutsch : A Three Stage Iterative Procedure for Space-Time Modeling ; Technometrics, Vol. 22, No. 1, pp. 35 47 (1980)
11) P. E. Pfeifer \& S. J. Deutsch : Identification and Interpretation of First Order Space-Time ARMA Models ; Technometrics, Vol. 22, No. 3, pp. 397 408 (1980)

12) P. E. Pfeifer \& S. J. Deutsch : Stationary and Invertibility Regions for Low-Order STARMA Models ; Communications in Statistics, Vol. B 9, No. 5, pp. 551 562 (1980)

13) G. E. P. Box \& G. M. Jenkins : Time Series Analysis, Forcasting and Control, Holden Day (1970)

14）赤松 : 情報量基準 AIC とは何か; 数理科学, Vol. 153, pp. 5 11 (1976)

15) 添田, 中海, 大松 : 信号処理の基礎之応用, 日新出版 (1979) 